\title{
Towards the development of a common starter culture for fufu and usi (edible starch): Screening for potential starters
}

\author{
Kubrat A. Oyinlola ${ }^{a *}$, Anthony A. Onilude ${ }^{a}$, And Oluwaseun E. Garuba \\ a Microbial Physiology and Biotechnology Unit, Department of Microbiology, Faculty of Science, University of \\ Ibadan, Nigeria \\ ${ }^{*}$ Corresponding author \\ bibimola.abiola@gmail.com \\ TEL: $+234(0) 7038257540$
}

Received: 27 April 2015; Published online: 18 April 2016

\begin{abstract}
Fermented cassava products like fufu and usi are important staple foods in many African homes. Natural fermentation time is usually long resulting in slower acidification and inconsistent nutritional composition of products which could be overcome with the use of starter culture. However, most available starters are used for single food fermentation and are uneconomical. This necessitates the development of a starter culture for multiple related food products to reduce cost. Hence, this study aimed at screening for potential starters in the development of a common starter culture for fufu and usi.

Fresh, peeled, chipped and grated cassava tubers were spontaneously fermented and lactic acid bacteria were isolated from the fermenting mash at 24 hour intervals. Ninety eight (98) isolates were randomly picked. Lactobacillus plantarum had highest occurrence (50.0\%) in both fermentations.

All selected isolates did not hydrolyze starch, but produced linamarase and pectinase. Fermenting $\mathrm{pH}$ ranged between 6.50 and 3.58 during 72 hours fermentation. Lactic acid concentration ranged from $1.10 \mathrm{~g} / \mathrm{L}$ to $1.78 \mathrm{~g} / \mathrm{L}$ at 24 hours, $1.22 \mathrm{~g} / \mathrm{L}$ to $2.45 \mathrm{~g} / \mathrm{L}$ at 48 hours and $0.57 \mathrm{~g} / \mathrm{L}$ to $2.55 \mathrm{~g} / 1$ at 72 hours. The highest hydrogen peroxide concentration produced was $629 \mu \mathrm{g} / \mathrm{L}$ at 24 hours while the least was $136 \mu \mathrm{g} / \mathrm{L}$ at 72 hours. $1.08 \mathrm{~g} / \mathrm{L}$ of diacetyl was the least concentration produced at 24 hours while the highest was $2.86 \mathrm{~g} / \mathrm{L}$ at 48 hours.

Five potential starters were identified as Lactobacillus pentosus F2A, L. plantarum subsp. argentolarensis F2B, L. plantarum F2C, L. plantarum U2A and L. paraplantarum U2C.
\end{abstract}

Keywords: Microbial starter; Fermented foods; Lactic acid bacteria; Fermentation

\section{Introduction}

Usi is one of the products of cassava fermentation. It is among the major staple foods of the Itsekiri and Urhobo in southern Nigeria, who also refer to it as edible starch (Etejere \& Bhat, 1985). The cassava starch was reported to be obtained through different techniques; it may be precipitated from the solution pressed out of the grated cassava roots or from grated cassava that is soaked directly in water.
Cassava roots are peeled, washed and grated. The grated pulp is steeped for 2-3 days in a large quantity of water then the mixture is stirred and filtered through a piece of cloth. The filtrate is allowed to stand overnight and the supernatant is then decanted. The fine starch paste is collected and put in a wide metal pan that is already smeared with red palm oil. Water is added and stirred with the hand to dissolve completely. The pot is put on fire and the solution constantly 
stirred with a wooden rod until it is converted to a very sticky, light yellow mass. This is eaten with any oil or soup (Etejere \& Bhat, 1985). Fufu was described by Sanni et al. (1998) as a fermented wet-paste from cassava and it is ranked next to gari as an indigenous food of most Nigerians. It is widely consumed almost across the country, with different preparation methods and ethnic names (Okafor, Ijioma, \& Oyolu, 1984; Oyewole \& Odunfa, 1989; Longe, 1980; Ayankunbi, Keshinro, \& Egele, 1991). Traditionally, peeled and washed cassava roots are manually cut into chunks of different sizes and soaked in earthen pots or drums of water for 3 to 5 days to undergo lactic acid fermentation. The roots are taken out, broken by hand and the fibres removed by sieving which is done by adding water to the retted mass on a nylon or cloth screen. The starch suspension is allowed to sediment in a large container for about 24 hours after which the water is decanted. The fine, clean starch is then dewatered by putting in raffia or cotton bags, then, pressed with heavy stones overnight (Oyewole \& Odunfa, 1989).

Fermentation still remains the best and widely used means of processing cassava into different products (Oyewole, 1992; Nweke, Dunstan, Spencer, \& Lyman, 2002) but chance inoculation (Oyewole \& Sanni, 1995), little or no control over the process (Oyewole, 1997), roots cut size (Okafor et al., 1984), difference in dry matter content (Hahn, 1989) and invasion by undesireable organisms characterizes the spontaneous process, thus, resulting in longer fermentation times as well as inconsistent final products (Kimaryo, Massawe, Olasupo, \& Holzapfel, 2000).

The controlled fermentation of some cassava products has been attributed to the use of microbial starter culture which is a preparation containing large number of viable microorganisms, mostly lactic acid bacteria (LAB) which often resulted in products of consistent properties (Holzapfel, 1997; Holzapfel, 2002). Lactobacillus plantarum has been shown to be the predominant LAB species during lactic fermentation (Lacerda et al., 2005; Kostinek et al., 2007). Starters are known to accelerate the fermentation process, antagonize undesirable microorganisms through the production of antimicrobial compounds, and improve both organoleptic and sen- sory attributes of the final product as well as ensuring a consistent product.

Some of the organisms reported to have been used as starters include amylolytic L. plantarum for gari and kivunde (Giraud, Gosselin, \& Raimbault, 1993; Kimaryo et al., 2000), L. coryneformis and Saccharomyces species for gari production, L. plantarum strains for fufu (Oyewole, 1990; Okolie, Ibeh, \& Ugochukwu, 1992) and so on. The development of a common starter for both products will be of economic importance, since most available starters are used for single food fermentation and are uneconomical thus, necessitating the development of a starter culture for multiple related food products to reduce cost. Hence, this study aimed at screening for potential starters in the development of a common starter culture for fufu and usi.

\section{Materials and Methods}

\subsection{Source of cassava tuber}

Cassava varieties TME 30572, TME 4(2)1425 and TME 50395 were obtained from the International Institute of Tropical Agriculture (IITA), Ibadan, Oyo State, Nigeria.

\subsection{Fermentation of Fufu and Usi}

The method of Oyewole and Odunfa (1989) was used in which the cassava roots were sorted by visual assessment, peeled, washed with clean tap water, and cut into small sizes. Two hundred grams of these were soaked submerged in 2 litres tap water in plastic fermenters of $10 \mathrm{~L}$ capacity for the 72 hours fermentation process under ambient condition $\left(30 \pm 2^{\circ} \mathrm{C}\right)$. The method of Etejere and Bhat (1985) was used for the fermentation of usi. Two hundred grams of cassava roots were grated and the pulp steeped in $2 \mathrm{~L}$ tap water in a $10 \mathrm{~L}$ capacity plastic fermenter for 3 days. Samples of fermenting mash were taken at 24 hours intervals for $\mathrm{LAB}$ isolation.

\section{$2.3 \quad$ Isolation of $\mathrm{LAB}$}

Ten grams of cassava sample were aseptically added to $90 \mathrm{~mL}$ of sterile peptone water and ho- 
Screening of potential starters for fufu and usi production $\mid 63$

mogenized for 2 minutes. Samples were further diluted in a tenfold serial dilution. Bacteria from higher dilutions were plated on sterile MRS agar (LabM, UK) and plates were incubated anaerobically at $30^{\circ} \mathrm{C}$ for 48 hours. Representative colonies were picked randomly and purified by repeated sub-culturing on fresh agar plates. Pure cultures were grown on agar slants and kept at $4^{\circ} \mathrm{C}$ for further use.

\subsection{Characterization of selected isolates}

Isolates were characterized on the basis of their microscopic, macroscopic and biochemical properties. Gram stain, catalase test, motility, production of $\mathrm{NH}_{3}$ from arginine, growth at different $\mathrm{NaCl}$ concentrations (4,6.5 and $8 \%$ ), starch and gelatine hydrolysis and production of acid from carbohydrates like glucose, sucrose, mannitol, sorbitol, raffinose, melibiose, fructose, maltose and galactose were analysed. Probable identities were confirmed using Bergey's Manual of Systematic Bacteriology (Holt, Krieg, Sneath, Stalely, \& Williams, 1994).

\subsection{Screening for potential starters}

Selected isolates were screened for starch hydrolysis on modified MRS agar (LabM, UK) containing $0.4 \%(\mathrm{w} / \mathrm{v})$ soluble starch as the sole carbon source. Plates were flooded with Gram's iodine after 24 hours incubation at $37^{\circ} \mathrm{C}($ Edward et al., 2012).

A chemically defined medium (CDM) containing pectin as carbon source was used to screen for pectinase production. Cultures were grown on MRS agar for 18 hours at $30^{\circ} \mathrm{C}$. Colonies were picked from the plates using a sterile loop and streaked on the CDM plate, then incubated for 24 hours. Colonies showing clear zones upon flooding with $1 \%$ cetyltrimethyl ammonium bromide were confirmed as pectinase producers (Al$\tan , 2004)$.

A medium containing $0.1 \mathrm{~g}$ of 4-nitrophenyl-BD-glucopyranoside (Sigma Aldrich, Germany) to $100 \mathrm{~mL} 0.666 \mathrm{M} \mathrm{NaH}_{2} \mathrm{PO}_{4}(\mathrm{pH}$ 6) was used to test for linamarase production. Twenty four hours old cultures were emulsified in physiologic saline to McFarland Turbidity Standard No. 3 after which $0.75 \mathrm{~mL}$ of culture was added to 0.25 $\mathrm{mL}$ of the test medium. It was incubated at $30^{\circ} \mathrm{C}$ overnight. Positive isolates that produced linamarase degraded the linamarin analogue ( $\beta$-glucosidase) and changed the colour of the mixture from colourless to a distinct yellow (Edward et al., 2012).

To monitor acidification in growth medium, selected isolates were inoculated into MRS broth (LabM, UK) that was prepared from a single batch which was $\mathrm{pH}$ adjusted ( $\mathrm{pH}$ 6.5) and then dispensed in $10 \mathrm{~mL}$ aliquots into sets of tubes before autoclaving. Incubation was done at $30^{\circ} \mathrm{C}$. Acidification was determined by measuring the $\mathrm{pH}$ of the culture medium at 24 hour intervals (Kostinek et al., 2005) and isolates with lower $\mathrm{pH}$ values were selected for further screening. Production of antimicrobial compounds (lactic acid, hydrogen peroxide and diacetyl) was carried out as described by Sanni, Fapohunda, and Onilude (1995) and Lönner, Welander, Molin, Dostalek, and Blickstad (1986).

Antibacterial activity of the selected isolates against pathogens (Escherichia coli, Bacillus cereus, Proteus sp., Salmonella sp., Corynebacterium sp. and Shigella sp.) collected from the Food Microbiology and Biotechnology Laboratory, Department of Microbiology, University of Ibadan was done according to the method of Kalalou, Faid, and Ahami (2004). MRS broth $(10 \mathrm{~mL})$ was inoculated with selected isolates and incubated at $37^{\circ} \mathrm{C}$ for 48 hours. A cell-free solution was obtained by centrifuging the bacterial culture at $6000 \mathrm{rpm}$ for 15 minutes followed by filtration of the supernatant through $0.2 \mathrm{~mm}$ pore size filter, thus, obtaining cell free filtrate. This was further utilised for the agar well diffusion assay (Schillinger \& Lucke, 1989).

\subsection{Molecular identification}

The DNA was extracted according to the procedure of Pitcher, Saunders, and Owen (1989) with some modifications. Bacteria culture grown overnight was centrifuged at $13000 \mathrm{rpm}$ for 2 minutes. Cell pellet was suspended in lysis buffer (pH 8.0) containing 25 Mm Tris-HCl (Sigma), 
$64 \mid$ Oyinlola et al.

$10 \mathrm{Mm}$ EDTA, $50 \mathrm{Mm}$ sucrose, $10 \mathrm{mg} / \mathrm{mL}$ lysozyme and incubated at $37^{\circ} \mathrm{C}$ for 30 minutes. Aliquots $(0.5 \mathrm{~mL})$ of the mixture of $5 \mathrm{M}$ guanidine thiocyanate, $0.1 \mathrm{~N}$ EDTA and $0.5 \%$ N-lauroylsarcosine sodium salt (Sigma, England) were added and incubated at $30^{\circ} \mathrm{C}$ for 15 minutes. Precipitation was done using chloroform: isoamyalcohol (24:1) and centrifugation at 13000 rpm for 10 minutes. Upper protein precipitate was removed, added to isopropanol and centrifuged for 5 minutes. Resultant pellets were then washed in $70 \%$ ethanol. Purification was done by dissolution in $1 \times$ TE buffer $(10 \mathrm{mM}$ Tris$\mathrm{HCl}$ and $1 \mathrm{mM}$ EDTA, $\mathrm{pH}$ 8.0) containing 10 $\mathrm{mg} / \mathrm{mL}$ of RNase and incubated at $37^{\circ} \mathrm{C}$ for 30 minutes. The bacterial universal primers $27 \mathrm{~F} 5$ 'AGAGTTTGATCCTGGCTCAG-3' and 1492R 5'-GGTTACCTTGTTACGACTT-3', previously shown to be useful for identification of lactic acid bacteria (Lane, 1991), were used to amplify approximately 600 base pairs of the rDNA gene-ITS region. The amplification method of Tajabadi, Mardan, Manap, and Mustafa (2013) was used. The PCR reaction was carried out in a total volume of $25 \mu \mathrm{L}$ with a reaction mixture with the following: $1 \times$ Taq Master Mix (Promega, UK), $1.5 \mathrm{mM} \mathrm{MgCl}, 0.25 \mathrm{mM}$ forward primer, $0.25 \mathrm{mM}$ reverse primer and 0.4 $\mathrm{mg}$ of genomic DNA. The reaction mixture in micro-centrifuge tube was amplified in a thermocycler PCR system (Techne-Progene, UK) in which an initial heating of $95^{\circ} \mathrm{C}$ for 3 minutes was followed by 40 cycles of denaturation at $95^{\circ} \mathrm{C}$ for 30 seconds, annealing at $55^{\circ} \mathrm{C}$ for 55 seconds, extension at $72^{\circ} \mathrm{C}$ for 1 minute, and terminating with a 10 minutes final incubation of $72^{\circ} \mathrm{C}$. The deduced DNA product was sequenced using an ABI Bigdye 3.1 sequencing kit (Applied Biosystems, California USA) on ABI 3730XL automated sequencing analyzer. The deduced sequences were subjected to BLAST search tool (www.ncbi.nlm.nih.gov) to obtain the closely related sequences in the $16 \mathrm{~S}$ rDNA database and they were further submitted to the GenBank for accession numbers.

\subsection{Data Analysis}

Experimental results were subjected to analysis of variance (ANOVA) and differences between means were assessed by Duncan's multiple range test at the significance defined at $\mathrm{P} \leq 0.05$ using SPSS 20.0 software.

\section{Results and Discussion}

A total number of ninety eight (98) strains of lactic acid bacteria (LAB) were isolated from the fermenting cassava mashes for both fufu (50) and usi (48), respectively. Their colonial morphology varied from small, medium to big colonies, shiny, creamy and whitish in colour.

Biochemical characterization (Table 1) showed the isolates to be Gram positive colonies of medium short and long rods, catalase negative, non-motile and do not hydrolyze starch and gelatin. Production of ammonia from arginine and growth at $6.5 \% \mathrm{NaCl}$ was also observed. Hydrogen sulphide was produced by all but were negative to methyl red test. Varied sugar utilization pattern was observed by the organisms where simple sugars (glucose, sucrose, fructose, lactose, maltose) were fermented by all.

The lactic acid bacteria were identified as Lactobacillus plantarum $(50.0 \%)$, L. acidilactici $(12.2 \%)$, L. brevis $(11.3 \%)$, L. fermentum (10.2\%), L. delbruekii (8.2\%), Leuconostoc mesenteroides (6.1\%) and L. lactis (2.0\%). L. plantarum had the total highest percentage of occurrence and isolates were selected for further screening. It has been established that it is important to isolate predominant strains from fermentation batches for starter development. The observation of $50 \%$ of the ninety eight (98) isolated organisms from this study being identified as Lactobacillus plantarum made the organism the most prevalent. This may be linked to the report that $L$. plantarum have a less complex nutritional requirement which is advantageous for metabolism compared to other Lactobacillus spp. (Hamnes, Weiss, \& Holzapfel, 1992). Apart from other bacterial genera associated with cassava fermentation, the different lactic acid bacteria species isolated in this study had earlier been reported to be involved in fermentation of cas- 
Screening of potential starters for fufu and usi production $\mid 65$

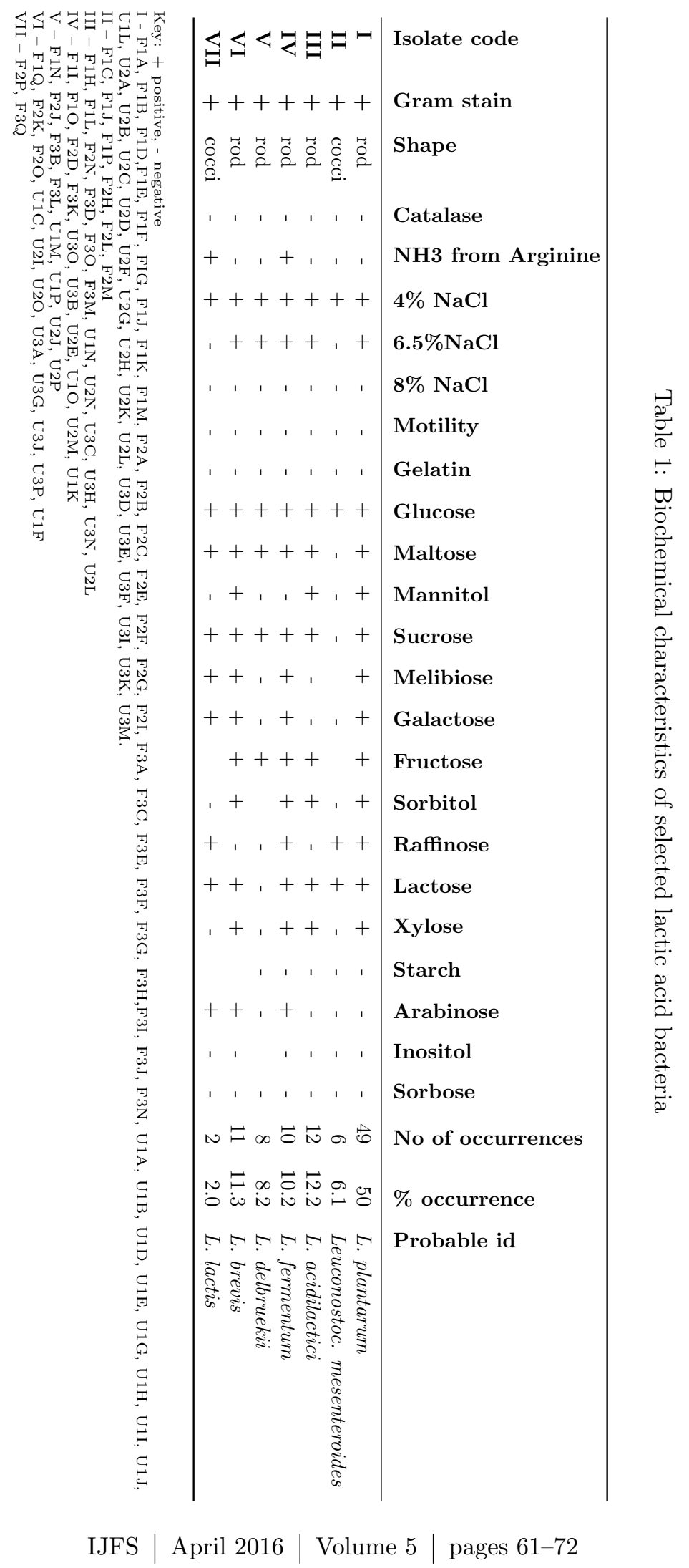


sava in numerous fermented food products (Abe \& Lindsay, 1978; Ngaba \& Lee, 1979; Oyewole \& Odunfa, 1988; Kobawila, Louembe, Keleke, Hounhouigan, \& Gamba, 2005).

Screening of organisms for starter development during cassava fermentation involves the ability of the microorganisms to produce microbial enzymes (amylase, linamarase, pectinase) which are essential for starch hydrolysis, cyanide detoxification and tissue disintegration, the ability to rapidly acidify the fermentation process as well as production of antimicrobial compounds which antagonise unwanted pathogens (Kostinek et al., 2007; Edward et al., 2012). All 48 selected isolates did not hydrolyze starch when grown on modified MRS agar but produced linamarase in the form of $\beta$-glucosidase and pectinase enzymes. This result was similar to earlier reports of Ketiku and Oyenuga (1972) which confirmed most lactic acid bacteria as non-amylolytic even though $84 \%$ of the cassava carbohydrate is in the form of starch. Amylase activity during fermentation could then be said to be induced, in the presence of starch since the utilised organisms could be referred to as non-amylolytic. However, contrary to earlier reports and that of this study, Oyewole (1995) reported over $80 \%$ of the total screened lactobacilli from fermented cassava as being amylolytic. The fact that they were isolated from a starch-based substrate did not determine their amylase-producing ability even though Mishra and Behera (2008) reported this factor to be advantageous.

All the screened strains produced linamarase and pectinase which are responsible for detoxification and tissue disintegration. Even though cassava may contain endogenous linamarase, certain microorganisms are responsible for the liberation of cyanide during fermentation through production of exogenous linamarase. Utilization of linamarase-producing organisms during cassava processing will improve the cyanide content of the final product.

Cassava contains pectin, a component that contributes to the firmness and structure of plant tissues. Submerged fermentation of cassava involved soaking the tubers in water, leading to swelling and softening of the tissues, however, pectinase enzyme has been reported to hydrolyse some of the pectin in and between cell wall making the cell weaker and therefore soft (Sakai \& Winkelmann, 1992) by decreasing intracellular adhesivity and tissue rigidity. Microbial strains that produce pectinase enzyme are thus required for cassava tissue disintegration.

Good $\mathrm{pH}$ reduction (a fast lowering of the $\mathrm{pH}$ ) is important to accelerate fermentation process as well as reduce the levels of contaminating microorganisms which can compete with the starters for nutrients (Holzapfel, 2002) and also a critical factor in developing flavour and aroma of foods (Montet, Loiseau, \& Zakhia-Rozis, 2006; Panda, Parmanick, \& Ray, 2007). Acidification in growth medium as monitored showed decrease in values with increase in incubation time, ranging from a starting $\mathrm{pH}$ of 6.50 to 3.58 after 72 hours incubation. The lowest $\mathrm{pH}$ at 24 hours was 4.62 by isolate $\mathrm{F} 2 \mathrm{~B}, 4.05$ at 48 hours by $\mathrm{U} 2 \mathrm{C}$ and 3.58 at 72 hours by isolate F2B (Table 2). The decrease in $\mathrm{pH}$ values during the fermentation of cassava roots could have resulted from the production of organic acids by lactic acid bacteria. Similar trend in reduction as observed in the screened isolates was reported (Kobawila et al., 2005; Coulin, Farah, Assanvo, Spillmann, \& Puhan, 2006) with a decrease in values with increasing fermentation time.

The preservative action of starter culture in food is being attributed to a wide range of metabolites produced during fermentation, as reported by Caplice and Fitzgerald (1999). Production of lactic acid, hydrogen peroxide and di-acetyl which are inhibitory compounds against pathogens by the selected isolates is shown in Tables 3-5 respectively. Lactic acid concentration produced ranged from $1.10 \mathrm{~g} / \mathrm{L}$ in isolate U3F to $1.78 \mathrm{~g} / \mathrm{L}$ in isolate $\mathrm{U} 2 \mathrm{C}$ at 24 hours, $1.22 \mathrm{~g} / \mathrm{L}$ in isolate $\mathrm{F} 1 \mathrm{~B}$ to $2.45 \mathrm{~g} / \mathrm{L}$ in isolate $\mathrm{F} 2 \mathrm{~A}$ at 48 hours and $0.57 \mathrm{~g} / \mathrm{L}$ and $2.55 \mathrm{~g} / \mathrm{L}$ in isolates F1F and U3J, respectively.

The highest hydrogen peroxide concentration produced was $629 \mu \mathrm{g} / \mathrm{L}$ by isolate $\mathrm{F} 2 \mathrm{~A}$ at 24 hours while the lowest was $136 \mu \mathrm{g} / \mathrm{L}$ by isolate U1D at 72 hours. The lowest diacetyl concentration $(1.08 \mathrm{~g} / \mathrm{L})$ was produced by both F2A and $\mathrm{U} 1 \mathrm{H}$ at 24 hours while the highest was $2.86 \mathrm{~g} / \mathrm{L}$ by F1B at 48 hours. Varied antimicrobial compound concentrations observed might be as a result of being produced by different LAB strains since Tannock (2004) linked production level and 
Screening of potential starters for fufu and usi production $\mid 67$

Table 2: Acidification of growth medium by selected Lactobacillus spp.

\begin{tabular}{|c|c|c|c|}
\hline \multirow[b]{2}{*}{ Isolate code } & \multicolumn{3}{|c|}{$\begin{array}{c}\text { Time (Hours)/ } \\
\text { Rate of acidification }\end{array}$} \\
\hline & 24 & 48 & 72 \\
\hline $\mathrm{F} 1 \mathrm{~A}$ & $5.33^{f}$ & $4.86^{k}$ & $4.52^{n}$ \\
\hline $\mathrm{F} 1 \mathrm{~B}$ & $5.26^{m}$ & $4.53^{y}$ & $4.43^{q}$ \\
\hline F1D & $5.27^{l}$ & $4.58^{x}$ & $4.5^{p}$ \\
\hline F1E & $5.06^{q}$ & $4.33^{z b}$ & $4.25^{w}$ \\
\hline $\mathrm{F} 1 \mathrm{~F}$ & $5.04^{s}$ & $4.68^{s}$ & $4.51^{\circ}$ \\
\hline $\mathrm{F} 1 \mathrm{G}$ & $5.35^{e}$ & $5.06^{f}$ & $4.64^{i}$ \\
\hline F1K & $5.32^{g}$ & $4.98^{g}$ & $4.71^{g}$ \\
\hline F1M & $5.29^{j}$ & $4.76^{\circ}$ & $4.41^{r}$ \\
\hline U1A & $5.27^{l}$ & $4.79^{n}$ & $4.73^{f}$ \\
\hline U1B & $5.31^{h}$ & $4.86^{k}$ & $4.52^{n}$ \\
\hline U1D & $5.15^{n}$ & $4.22^{z f}$ & $4.17^{z a}$ \\
\hline $\mathrm{U} 1 \mathrm{E}$ & $5.3^{i}$ & $5.1^{d}$ & $4.82^{c}$ \\
\hline $\mathrm{U} 1 \mathrm{G}$ & $5.36^{d}$ & $4.9^{i}$ & $4.62^{k}$ \\
\hline $\mathrm{U} 1 \mathrm{H}$ & $4.94^{x}$ & $4.29^{z c}$ & $4.25^{w}$ \\
\hline U1I & $5.32^{g}$ & $4.98^{g}$ & $4.71^{g}$ \\
\hline U1J & $5.28^{k}$ & $4.68^{s}$ & $4.61^{l}$ \\
\hline U1L & $5.41^{\mathrm{c}}$ & $5.18^{\mathrm{b}}$ & $4.63^{\mathrm{j}}$ \\
\hline $\mathrm{F} 2 \mathrm{~A}$ & $4.75^{\mathrm{zc}}$ & $4.06^{\mathrm{zh}}$ & $4.01^{\mathrm{zd}}$ \\
\hline $\mathrm{F} 2 \mathrm{~B}$ & $4.62^{\mathrm{zd}}$ & $3.66^{\mathrm{zj}}$ & $3.58^{\mathrm{ze}}$ \\
\hline $\mathrm{F} 2 \mathrm{C}$ & $4.89^{\mathrm{z}}$ & $4.29^{\mathrm{zc}}$ & $4.18^{\mathrm{z}}$ \\
\hline $\mathrm{F} 2 \mathrm{E}$ & $4.93^{y}$ & $4.33^{\mathrm{zb}}$ & $4.27^{\mathrm{v}}$ \\
\hline $\mathrm{F} 2 \mathrm{~F}$ & $5.36^{\mathrm{d}}$ & $5.09^{\mathrm{e}}$ & $4.74^{\mathrm{e}}$ \\
\hline $\mathrm{F} 2 \mathrm{G}$ & $5.3^{\mathrm{i}}$ & $5.1^{\mathrm{d}}$ & $4.82^{\mathrm{c}}$ \\
\hline F2I & $5.31^{\mathrm{h}}$ & $4.87^{\mathrm{j}}$ & $4.68^{\mathrm{h}}$ \\
\hline $\mathrm{F} 2 \mathrm{~J}$ & $5.28^{\mathrm{k}}$ & $4.68^{\mathrm{s}}$ & $4.61^{1}$ \\
\hline $\mathrm{U} 2 \mathrm{~A}$ & $4.82^{\mathrm{za}}$ & $4.13^{\mathrm{zg}}$ & $4.05^{\mathrm{zc}}$ \\
\hline $\mathrm{U} 2 \mathrm{~B}$ & $5.3^{\mathrm{i}}$ & $5.1^{\mathrm{d}}$ & $4.82^{\mathrm{c}}$ \\
\hline $\mathrm{U} 2 \mathrm{C}$ & $4.76^{\mathrm{zb}}$ & $4.05^{\mathrm{zi}}$ & $4.01^{\mathrm{zd}}$ \\
\hline $\mathrm{U} 2 \mathrm{D}$ & $5.27^{1}$ & $4.73^{\mathrm{q}}$ & $4.61^{1}$ \\
\hline $\mathrm{U} 2 \mathrm{~F}$ & $4.99^{\mathrm{u}}$ & $4.26^{\mathrm{ze}}$ & $4.26^{\mathrm{v}}$ \\
\hline $\mathrm{U} 2 \mathrm{G}$ & $5.31^{\mathrm{h}}$ & $4.85^{1}$ & $4.76^{\mathrm{d}}$ \\
\hline $\mathrm{U} 2 \mathrm{H}$ & $5.28^{\mathrm{k}}$ & $4.68^{\mathrm{s}}$ & $4.61^{1}$ \\
\hline $\mathrm{U} 2 \mathrm{~K}$ & $5.32^{\mathrm{g}}$ & $4.92^{\mathrm{h}}$ & $4.61^{1}$ \\
\hline U2L & $5.29^{\mathrm{j}}$ & $4.6^{\mathrm{v}}$ & $4.39^{\mathrm{s}}$ \\
\hline F3A & $4.95^{\mathrm{w}}$ & $4.33^{\mathrm{zb}}$ & $4.22^{\mathrm{y}}$ \\
\hline F3C & $4.97^{\mathrm{v}}$ & $4.22^{\mathrm{zf}}$ & $4.18^{\mathrm{z}}$ \\
\hline F3E & $5.06^{\mathrm{q}}$ & $4.64^{\mathrm{u}}$ & $4.52^{\mathrm{n}}$ \\
\hline F3F & $5.3^{\mathrm{i}}$ & $4.72^{\mathrm{r}}$ & $4.68^{\mathrm{h}}$ \\
\hline F3G & $5.15^{\mathrm{n}}$ & $4.28^{\mathrm{zd}}$ & $4.23^{\mathrm{x}}$ \\
\hline F3H & $5.27^{1}$ & $4.74^{\mathrm{p}}$ & $4.31^{\mathrm{t}}$ \\
\hline F3I & 5.32 & $4.82^{\mathrm{m}}$ & $4.59^{\mathrm{m}}$ \\
\hline F3J & $5.44^{\mathrm{a}}$ & $5.17^{\mathrm{c}}$ & $4.93^{\mathrm{b}}$ \\
\hline F3N & $5^{\mathrm{t}}$ & $4.59^{\mathrm{w}}$ & $4.31^{\mathrm{t}}$ \\
\hline U3D & $5.12^{\circ}$ & $4.26^{\mathrm{ze}}$ & $4.09^{\mathrm{zb}}$ \\
\hline U3E & $5.29^{j}$ & $4.65^{\mathrm{t}}$ & $4.59^{\mathrm{m}}$ \\
\hline $\mathrm{U} 3 \mathrm{~F}$ & $5.05^{\mathrm{r}}$ & $4.42^{\mathrm{z}}$ & $4.26^{\mathrm{v}}$ \\
\hline U3I & $5.42^{\mathrm{b}}$ & $5.31^{\mathrm{a}}$ & $5.1^{\mathrm{a}}$ \\
\hline U3K & $5.07^{\mathrm{p}}$ & $4.35^{\mathrm{za}}$ & $4.23^{\mathrm{x}}$ \\
\hline $\mathrm{U} 3 \mathrm{M}$ & $5.3^{\mathrm{i}}$ & $4.82^{\mathrm{m}}$ & $4.71^{\mathrm{ge}}$ \\
\hline
\end{tabular}

Bold values: Twenty least $\mathrm{pH}$ values. Values with same superscript in the same column indicated no significant difference at $5 \%$ level of probability
Table 3: Production of lactic acid by selected Lactobacillus spp

\begin{tabular}{llll}
\hline & \multicolumn{3}{c}{ Time (Hours)/ } \\
& \multicolumn{3}{c}{ Lactic acid (g/L) } \\
\hline Isolate code & $\mathbf{2 4}$ & $\mathbf{4 8}$ & $\mathbf{7 2}$ \\
\hline F2A & $1.24^{m}$ & $2.45^{a}$ & $0.74^{m}$ \\
F2B & $1.48 \mathrm{~h}^{\mathrm{ij}}$ & $1.69^{i}$ & $1.13^{g}$ \\
F2C & $1.71^{b}$ & $1.62^{j}$ & $1.03^{h}$ \\
F2E & $1.57^{\mathrm{de}}$ & $1.81^{h}$ & $0.98^{i}$ \\
U2A & $1.50^{\text {ghi }}$ & $2.34^{b}$ & $1.23^{f}$ \\
U2C & $1.78^{a}$ & $2.18^{c}$ & $0.78^{l}$ \\
U2F & $1.64^{c}$ & $1.64^{j}$ & $0.83^{k}$ \\
F1B & $1.57^{\text {de }}$ & $1.22^{n}$ & $0.94^{j}$ \\
F1D & $1.54^{\text {efg }}$ & $1.47^{k}$ & $0.74^{m}$ \\
F1E & $1.33^{l}$ & $2.10^{d}$ & $0.79^{l}$ \\
F1F & $1.30^{l}$ & $1.93^{f}$ & $0.57^{o}$ \\
U1D & $1.59^{d}$ & $1.47^{k}$ & $0.72^{m}$ \\
U1H & $1.45^{\mathrm{jk}}$ & $1.48^{k}$ & $1.15^{g}$ \\
F3C & $1.46^{\mathrm{ij}}$ & $1.86^{g}$ & $2.11^{e}$ \\
F3A & $1.18^{n}$ & $1.26^{m}$ & $0.69^{n}$ \\
F3E & $1.41^{j}$ & $1.37^{l}$ & $2.39^{c}$ \\
U3D & $1.58^{\mathrm{de}}$ & $1.88^{g}$ & $2.46^{b}$ \\
U3F & $1.10^{o}$ & $1.99^{e}$ & $2.25^{d}$ \\
U3J & $1.51^{\text {fgh }}$ & $1.86^{g}$ & $2.55^{a}$ \\
F3G & $1.55^{\text {def }}$ & $2.07^{\mathrm{d}}$ & $1.14^{\mathrm{g}}$ \\
\hline
\end{tabular}

The means reported with the same superscript indicated no significant difference at $0.05 \%$ level of probability

proportion to be dependent on strains, medium compounds and physical parameters.

The best five overall producers after being analyzed statistically, using Duncan Multiple Range Test at $0.05 \%$ level of probability, across the three compounds are F2A, F2B, F2C, U2A and $\mathrm{U} 2 \mathrm{C}$. They were thus selected as the potential starters and identified genotypically.

The antimicrobial activity of the five selected potential starters against pathogenic organisms indicated that most of the isolates inhibited the growth of the pathogens by showing zones of inhibition around the colonies whereas few showed no inhibition zones at all, most especially against Corynebacterium sp. (Table 6). The inhibition zones observed in this study ranged between 2 $\mathrm{mm}$ and $12 \mathrm{~mm}$.

The LAB isolates showed inhibition against E. coli, Salmonella sp., Bacillus cereus and Shigellasp. Isolate U2C did not inhibit the growth of Corynebacterium sp., having $7 \mathrm{~mm}$ inhibition zone while only U2A showed no in- 
$68 \mid$ Oyinlola et al.

Table 4: Production of hydrogen peroxide by selected Lactobacillus spp

\begin{tabular}{llll}
\hline & \multicolumn{3}{c}{ Time (Hours)/ } \\
& Hydrogen & peroxide $(\mu \mathrm{g} / \mathbf{L})$ \\
\hline Isolate code & $\mathbf{2 4}$ & $\mathbf{4 8}$ & $\mathbf{7 2}$ \\
\hline F2A & $629^{a}$ & $34^{a}$ & $204^{\mathrm{c}}$ \\
F2B & $442^{b}$ & $272^{e}$ & $221^{b}$ \\
F2C & $238^{j}$ & $323^{b}$ & $221^{b}$ \\
F2E & $187^{l}$ & $204^{i}$ & $17^{e}$ \\
U2A & $272^{i}$ & $255^{f}$ & $187^{d}$ \\
U2C & $323^{g}$ & $306^{c}$ & $187^{d}$ \\
U2F & $306^{h}$ & $221^{h}$ & $204^{\mathrm{c}}$ \\
F1B & $34^{f}$ & $289^{d}$ & $204^{\mathrm{c}}$ \\
F1D & $357^{e}$ & $238^{g}$ & $221^{b}$ \\
F1E & $391^{\mathrm{c}}$ & $204^{i}$ & $204^{\mathrm{c}}$ \\
F1F & $306^{h}$ & $204^{i}$ & $374^{a}$ \\
U1D & $323^{g}$ & $238^{g}$ & $136^{g}$ \\
U1H & $374^{d}$ & $204^{i}$ & $187^{d}$ \\
F3C & $221^{k}$ & $323^{b}$ & $153^{f}$ \\
F3A & $391^{c}$ & $255^{f}$ & $204^{\mathrm{c}}$ \\
F3E & $238^{j}$ & $204^{i}$ & $204^{\mathrm{c}}$ \\
U3D & $374^{d}$ & $204^{i}$ & $204^{\mathrm{c}}$ \\
U3F & $357^{e}$ & $187^{\mathrm{j}}$ & $221^{\mathrm{b}}$ \\
U3J & $374^{d}$ & $204^{\mathrm{i}}$ & $18^{\mathrm{d}}$ \\
F3G & $323^{g}$ & $289^{\mathrm{d}}$ & $204^{\mathrm{cg}}$ \\
\hline
\end{tabular}

The means reported with the same superscript indicated no significant difference at $0.05 \%$ level of probability.

hibition against Proteus sp. Similar antagonistic effect has been reported from LAB isolated from different sources including dairy products (Saranya \& Hemashenpagam, 2011), fermented maize products (Omemu \& Faniran, 2011), fermented fish (Liasi et al., 2009), poultry meat (Adesokan, Odetoyinbo, \& Olubamiwa, 2008) and cow milk (Olanrewaju, 2007).

The result of the $16 \mathrm{~S}$ rDNA sequence of the five bacterial isolates as shown in Table 7 on the basis of the database information available on National Centre for Biotechnology Information (NCBI) site using the Basic Local Alignment Search Tool (BLAST), classified and identified the isolates using the highest percentage similarity with organisms of the nearest homology. All the isolates belonged to the family Lactobacillaceaeand genus Lactobacillus.

Lactobacillus pentosus F2A (accession number KJ778115) showed 99\% 16S rDNA homology alignment with $L$. pentosus strain 405 , L. plantarum subsp. argentolarensis F2B (KJ778116)
Table 5: Production of diacetyl by selected Lactobacillus spp

\begin{tabular}{|c|c|c|c|}
\hline \multirow[b]{2}{*}{ Isolate code } & \multicolumn{3}{|c|}{$\begin{array}{l}\text { Time (Hours)/ } \\
\text { Diacetyl (g/L) }\end{array}$} \\
\hline & 24 & 48 & 72 \\
\hline $\mathrm{F} 2 \mathrm{~A}$ & $1.08^{J}$ & $1.91^{i}$ & $1.72^{i}$ \\
\hline $\mathrm{F} 2 \mathrm{~B}$ & $1.72^{f}$ & $2.35^{d}$ & $2.18^{\mathrm{cd}}$ \\
\hline $\mathrm{F} 2 \mathrm{C}$ & $1.91^{\mathrm{je}}$ & $2.51^{c}$ & $2.31^{b}$ \\
\hline $\mathrm{F} 2 \mathrm{E}$ & $2^{d}$ & $2.82^{a}$ & $2.51^{a}$ \\
\hline $\mathrm{U} 2 \mathrm{~A}$ & $2.11^{c}$ & $2.25^{\mathrm{ef}}$ & $2.1^{e}$ \\
\hline $\mathrm{U} 2 \mathrm{C}$ & $1.51^{i}$ & $2.1 \mathrm{~g}$ & $1.98^{\text {fgh }}$ \\
\hline $\mathrm{U} 2 \mathrm{~F}$ & $1.09^{j}$ & $1.97^{\mathrm{hi}}$ & $1.77^{i}$ \\
\hline F1B & $2.33^{a}$ & $2.86^{a}$ & $2.52^{a}$ \\
\hline F1D & $1.98^{d}$ & $2.1^{g}$ & $1.9^{h}$ \\
\hline F1E & $1.56^{h}$ & $2^{h}$ & $1.72^{i}$ \\
\hline $\mathrm{F} 1 \mathrm{~F}$ & $1.91^{e}$ & $2.32^{\mathrm{de}}$ & $2.13^{\mathrm{de}}$ \\
\hline U1D & $2.1^{c}$ & $2.61^{b}$ & $2.23^{c}$ \\
\hline $\mathrm{U} 1 \mathrm{H}$ & $1.08^{j}$ & $2.22^{f}$ & $1.96^{\mathrm{fg}}$ \\
\hline F3C & $1.62^{g}$ & $1.98^{\mathrm{hi}}$ & $1.72^{i}$ \\
\hline F3A & $1.52^{\mathrm{ki}}$ & $1.98^{\mathrm{hi}}$ & $1.77^{i}$ \\
\hline F3E & $2.21^{b}$ & $2.51^{c}$ & $2.32^{b}$ \\
\hline U3D & $1.99^{d}$ & $2.13^{g}$ & $2.01^{f}$ \\
\hline U3F & $2.33^{a}$ & $2.64^{b}$ & $2.38^{b}$ \\
\hline U3J & $1.56^{h}$ & $1.99^{h}$ & $1.7^{i}$ \\
\hline F3G & $1.73^{f}$ & $2.13^{g}$ & $1.93^{\mathrm{gh}}$ \\
\hline
\end{tabular}

The means reported with the same superscript indicated no significant difference at $0.05 \%$ level of probability.

showed $99 \%$ nucleotide homology with L. plantarum subsp. argentolarensis while L. plantarum F2C (KJ77117) showed 99\% homology with $L$. plantarum 097 (JN560914). 100\% similarity was observed between L. plantarum U2A (KJ78118) and L. plantarum $\mathrm{P} 2$ whereas $L$. paraplantarum U2C (KJ778119) was $99 \%$ homologous with $L$. paraplantarum DSM10667 sequence in the NCBI Genbank.

\section{Conclusions}

Analysing two similar fermented food products for the purpose of developing a common starter for their fermentation is beneficial as an alternative to utilising individual starter for each food product considering that starters are commercially not economical. In the present study, genotypically identified potential starters L. plantarum (3 isolates), L. pentosus ( 1 isolate) and $L$. paraplantarum (1 isolate) were selected after screening and utilization of the or- 
Screening of potential starters for fufu and usi production $\mid 69$

Table 6: Antimicrobial susceptibility of selected isolates against test pathogenic organisms

\begin{tabular}{ccccccc}
\hline & \multicolumn{5}{c}{ Pathogenic test organisms / Zone of inhibition $(\mathrm{mm})$} \\
\hline Isolates & E. coli & Proteus sp. & Salmonella sp. & B. cereus & Shigella sp. & Corynebacterium sp. \\
\hline F2A & 6 & 2 & 6 & 4 & 12 & NI \\
F2B & 6 & 2 & 8 & 4 & 9 & NI \\
F2C & 6 & 3 & 7 & 3 & 11 & NI \\
U2A & 9 & NI & 7 & 6 & 10 & 7 \\
U2C & 6 & 2 & 7 & 2 & 9 & \\
\hline
\end{tabular}

Key: NI - No Inhibition

Table 7: Molecular identification of selected potential starters

\begin{tabular}{|c|c|c|c|c|c|}
\hline $\begin{array}{l}\text { Isolate } \\
\text { code }\end{array}$ & $\begin{array}{l}\text { Closely related species/ } \\
\text { GenBank Accession number }\end{array}$ & $\begin{array}{l}\text { Percent } \\
\text { similarity }\end{array}$ & $\begin{array}{l}\text { Bp } \\
\text { analyzed }\end{array}$ & Identification & $\begin{array}{l}\text { GenBank } \\
\text { Accession number }\end{array}$ \\
\hline F2A & L. pentosus 405 (AB775188) & 99 & 517 & L. pentosus & KJ778115 \\
\hline F2B & $\begin{array}{l}\text { L. plantarum subsp. } \\
\text { argentolarensis Ni1031(AB598953) }\end{array}$ & 99 & 496 & $\begin{array}{l}\text { L. plantarum subsp. } \\
\text { argentolarensis }\end{array}$ & KJ778116 \\
\hline F2C & L. plantarum 097 (JN560914) & 99 & 521 & L. plantarum & KJ778117 \\
\hline U2A & L. plantarum P2 (EU167523) & 100 & 500 & L. plantarum & KJ778118 \\
\hline $\mathrm{U} 2 \mathrm{C}$ & $\begin{array}{l}\text { L. paraplantarum DSM10667 } \\
\text { (NR117813) }\end{array}$ & 99 & 520 & L. paraplantarum & KJ778119 \\
\hline
\end{tabular}

ganisms both singly and in combination for further selection of a common starter for the production of both fufu and usi is ongoing. * No conflict of interest declared by authors.

\section{References}

Abe, M. O. \& Lindsay, R. C. (1978). Evidence for a lactic streptococcal role in nigerian acidic cassava (manihot-esculenta crantz) fermentations. Journal of Food Protection, 41(10), 781-784.

Adesokan, I. A., Odetoyinbo, B. B., \& Olubamiwa, A. O. (2008). Biopreservative activity of lactic acid bacteria on suya produced from poultry meat. African Journal of Biotechnology, 7(20), 3796-3800.

Altan, A. (2004). Isolation and molecular characterization of extracellular lipase and pectinase producing bacteria from olive oil mills (Doctoral dissertation, İzmir Institute of Technology).

Ayankunbi, M. A., Keshinro, O. O., \& Egele, P. (1991). Effect of methods of preparation on the nutrient composition of some cassava products - garri (eba), lafun and fufu. Food Chemistry, 41(3), 349-354. doi:10.1016/ 0308-8146(91)90059-W

Caplice, E. \& Fitzgerald, G. F. (1999). Food fermentations: role of microorganisms in food production and preservation. International Journal of Food Microbiology, 50(1-2), 131-149. 17th International Conference on Ecology and Physiology of Food Related Micro-Organisms (FOOD MICRO 99), VELDHOVEN, NETHERLANDS, SEP 13-17, 1999. doi:10.1016/ S0168-1605(99)00082-3

Coulin, P., Farah, Z., Assanvo, J., Spillmann, H., \& Puhan, Z. (2006). Characterisation of the microflora of attieke, a fermented cassava product, during traditional smallscale preparation. International Journal of Food Microbiology, 106(2), 131-136. doi:10. 1016/j.ijfoodmicro.2005.06.012

Edward, V. A., Egounlety, M., Huch, M., Van Zyl, P. J., Singh, S., Nesengani, N. D., ... Franz, C. M. A. P. (2012). Isolation and screening of microorganisms from a gari fermentation process for starter culture de- 
velopment. African Journal of Biotechnology, 11 (65), 12865-12877.

Etejere, E. O. \& Bhat, R. B. (1985). Traditional preparation and uses of cassava in nigeria. Economic Botany, 39(2), 157-164. doi:10. 1007/BF02907839

Giraud, E., Gosselin, L., \& Raimbault, M. (1993). Production of a lactobacillusplantarum starter with linamarase and amylase activities for cassava fermentation. Journal of the Science of Food and Agriculture, 62(1), 77-82. doi:10.1002/jsfa . 2740620111

Hahn, S. K. (1989). An overview of african traditional cassava processing and utilization. Outlook on Agriculture, 18(3), 110-118.

Hamnes, W. P., Weiss, N., \& Holzapfel, W. (1992). The genera lactobacillus and carnobacterium. Springer-Verlag.

Holt, J. G., Krieg, N. R., Sneath, P. H., Stalely, J. T., \& Williams, S. T. (1994). Bergey's manual of determinative bacteriology. Bergey's Manual of Determinative Bacteriology. Williams \& Wilkins. Retrieved from https: / / books.google.pt/ books?id=jtMLzaa5ONcC

Holzapfel, W. (1997). Use of starter cultures in fermentation on a household scale. Food Control, 8(5-6), 241-258. FAO/WHO Workshop on the Assessment of Fermentation as a Household Technology for Improving Food Safety, PRETORIA, SOUTH AFRICA, DEC 11-15, 1995. doi:10.1016/ S0956-7135(97)00017-0

Holzapfel, W. H. (2002). Appropriate starter culture technologies for small-scale fermentation in developing countries. International Journal of Food Microbiology, 75(3, SI), 197-212. Annual Meeting of the Institute-of-Food-Technologists, KEMPTHALL, SWITZERLAND, 1999. doi:10.1016/S0168-1605(01)00707-3

Kalalou, I., Faid, M., \& Ahami, A. T. (2004). Extending shelf life of fresh minced camel meat at ambient temperature by lactobacillus dlbrueckii subsp delbrueckii. Electronic Journal of Biotechnology, 7(3).

Ketiku, A. O. \& Oyenuga, V. A. (1972). Changes in carbohydrate consitituents of cassava root-tuber (manihot-utilissima pohl) dur- ing growth. Journal of the Science of Food and Agriculture, 23(12), 1451-1456. doi:10. $1002 /$ jsfa.2740231209

Kimaryo, V. M., Massawe, G. A., Olasupo, N. A., \& Holzapfel, W. H. (2000). The use of a starter culture in the fermentation of cassava for the production of "kivunde", a traditional tanzanian food product. International Journal of Food Microbiology, 56(23), 179-190. doi:10.1016/S0168-1605(00) 00159-8

Kobawila, S., Louembe, D., Keleke, S., Hounhouigan, J., \& Gamba, C. (2005). Reduction of the cyanide content during fermentation of cassava roots and leaves to produce bikedi and ntoba mbodi, two food products from congo. African Journal of Biotechnology, 4(7), 689-696.

Kostinek, M., Specht, I., Edward, V. A., Pinto, C., Egounlety, M., Sossa, C., .. . Holzapfel, W. H. (2007). Characterisation and biochemical properties of predominant lactic acid bacteria from fermenting cassava for selection as starter cultures. International Journal of Food Microbiology, 114(3), 342351. doi:10.1016/j.ijfoodmicro.2006.09.029

Kostinek, M., Specht, I., Edward, V., Schillinger, U., Hertel, C., Holzapfel, W., \& Franz, C. (2005). Diversity and technological properties of predominant lactic acid bacteria from fermented cassava used for the preparation of gari, a traditional african food. Systematic and Applied Microbiology, 28(6), 527-540. doi:10.1016/j.syapm.2005. 03.001

Lacerda, I., Miranda, R., Borelli, B., Nunes, A., Nardi, R., Lachance, M., \& Rosa, C. (2005). Lactic acid bacteria and yeasts associated with spontaneous fermentations during the production of sour cassava starch in brazil. International Journal of Food Microbiology, 105(2), 213-219. doi:10. 1016/j.ijfoodmicro.2005.04.010

Lane, D. J. (1991). 16s/23s rrna sequencing. $N u$ cleic acid techniques in bacterial systematics, 125-175.

Liasi, S. A., Azmi, T. I., Hassan, M. D., Shuhaimi, M., Rosfarizan, M., \& Ariff, A. B. (2009). Antimicrobial activity and antibiotic sensitivity of three isolates of lac- 
Screening of potential starters for fufu and usi production $\mid 71$

tic acid bacteria from fermented fish product, budu. Malaysian Journal of Microbiology, 5(1), 33-37.

Longe, O. G. (1980). Effect of processing on the chemical-composition and energy value of cassava. Nutrition Reports International, $21(6), 819-828$.

Lönner, C., Welander, T., Molin, N., Dostalek, M., \& Blickstad, E. (1986). The microflora in a sour dough started spontaneously on typical swedish rye meal. Food Microbiology, 3(1), 3-12.

Mishra, S. \& Behera, N. (2008). Amylase activity of a starch degrading bacteria isolated from soil receiving kitchen wastes. African Journal of Biotechnology, 7(18), 3326-3331.

Montet, D., Loiseau, G., \& Zakhia-Rozis, N. (2006). Microbial technology of fermented vegetables. Microbial Biotechnology in Horticulture, 1, 309-343.

Ngaba, P. R. \& Lee, J. S. (1979). Fermentation of cassava (manihot-esculenta crantz). Journal of Food Science, 44 (5), 1570-1571. doi:10.1111/j.1365-2621.1979.tb06496.x

Nweke, F., Dunstan, S., Spencer, D., \& Lyman, J. (2002). The cassava transformation. Michigan State: University press, 8992.

Okafor, N., Ijioma, B., \& Oyolu, C. (1984). Studies on the microbiology of cassava retting for foo-foo production. Journal of Applied Bacteriology, 56(1), 1-13. doi:10.1111/j . 1365-2672.1984.tb04691.x

Okolie, N. P., Ibeh, I. N., \& Ugochukwu, E. N. (1992). Production of improved cassava fufu, akpu, through controlled fermentation. Food Chemistry, 44(2), 137-139. doi:10.1016/0308-8146(92)90326-W

Olanrewaju, O. (2007). Antagonistic effect of lactobacillus isolates from kunnu and cowmilk on selected pathogenic microorganisms. Internet Journal of food safety, 9, 63-66.

Omemu, A. M. \& Faniran, O. W. (2011). Assessment of the antimicrobial activity of lactic acid bacteria isolated from two fermented maize products-ogi and kunnuzaki. Malaysian Journal of Microbiology, 7(3), 124-128.

Oyewole, O. B. (1990). Optimization of cassava fermentation for fufu production - effects of single starter cultures. Journal of Applied Bacteriology, 68(1), 49-54. doi:10.1111/j. 1365-2672.1990.tb02547.x

Oyewole, O. B. (1992). Cassava processing in africa. Application of Biotechnology to traditional fermented foods. National Research Council [USA]. National Academy Press. Washington, DC. USA.(ISBN 0309-04685). Pg, 89-92.

Oyewole, O. B. (1995). Application of biotechnology to cassava processing in africa $=$ utilisation des biotechnologies à l'amélioration de la transformation du manioc en afrique. Agbor-Egbe, Tom; Brauman, Alain; Griffon, Dany; Treche, Serge (eds.). Transformation alimentaire du manioc $=$ Cassava food processing.

Oyewole, O. B. (1997). Lactic fermented foods in africa and their benefits. Food Control, 8(56), 289-297. doi:10.1016/S0956-7135(97) $00075-3$

Oyewole, O. B. \& Odunfa, S. A. (1988). Microbiological studies on cassava fermentation for lafunproduction. Food microbiology, 5(3), $125-133$.

Oyewole, O. B. \& Odunfa, S. A. (1989). Effects of fermentation on the carbohydrate, mineral, and protein contents of cassava during fufu production. Journal of Food Composition and Analysis, 2(2), 170-176. doi:h10.1016/ 0889-1575(89)90078-1

Oyewole, O. B. \& Sanni, L. O. (1995). Constraints in traditional cassava processing: the case of" fufu" production= les contraintes au cours de la transformation traditionnelle du manioc: le cas de la production de foufou. Agbor-Egbe, Tom; Brauman, Alain; Griffon, Dany; Treche, Serge (eds.). Transformation alimentaire du manioc = Cassava food processing.

Panda, S. H., Parmanick, M., \& Ray, R. C. (2007). Lactic acid fermentation of sweet potato (ipomoea batatas 1.) into pickles. Journal of Food Processing and Preservation, 31(1), 83-101. doi:10.1111/j.17454549.2007.00110.x

Pitcher, D. G., Saunders, N. A., \& Owen, R. J. (1989). Rapid extraction of bacterial genomic dna with guanidium thiocyanate. Letters in Applied Microbiology, 8(4), 151-

IJFS | April 2016 | Volume 5 | pages 61-72 
156. doi:10 . 1111/j . 1472 - 765X . 1989 . tb00262.x

Sakai, T. \& Winkelmann, G. (1992). Degradation of pectins. Microbial degradation of natural products. 57-81.

Sanni, A. I., Fapohunda, E. M., \& Onilude, A. A. (1995). Characteristic properties of lactic acid bacteria isolated from the rumen of maradi goats. Chemie, Mikrobiologie, Technologie der Lebensmittel, 17(3-4), 99-104.

Sanni, L. O., Akingbala, J. O., Oguntunde, A. O., Bainbridge, Z. A., Graffham, A. J., \& Westby, A. (1998). Processing of fufu from cassava in nigeria: problems and prospects for development. Science, Technology and Development (United Kingdom), 16(1), 5871. Retrieved from http: //r4d.dfid.gov.uk/Output/55963/

Saranya, S. \& Hemashenpagam, N. (2011). Antagonistic activity and antibiotic sensitivity of lactic acid bacteria from fermented dairy products. Advances in Applied Science Research, 2(4), 528-534.

Schillinger, U. \& Lucke, F. K. (1989). Antibacterial activity of lactobacillus-sake isolated from meat. Applied and Environmental Microbiology, 55(8), 1901-1906.

Tajabadi, N., Mardan, M., Manap, M. Y. A., \& Mustafa, S. (2013). Molecular identification of lactobacillus spp. isolated from the honey comb of the honey bee (apis dorsata) by 16 s rrna gene sequencing. Journal of Apicultural Research, 52(5). doi:10. 3896/IBRA.1.52.5.10

Tannock, G. W. (2004). A special fondness for lactobacilli. Applied and Environmental Microbiology, 70(6), 3189-3194. doi:10. 1128/AEM.70.6.3189-3194.2004 